\title{
Impact of Organization Politics on Human Resource Management Practices and Employee Performance
}

Rehana Yasmeen

Munaza Bibi ${ }^{1}$

Ali Raza

Article History

Received 2019-02-18

Accepted 2019-02-19

Published 2019-02-22

Keywords

Organization Politics,

Nepotism,

Favoritism,

HRM Practices,

Employee Performance

How to cite?

Yasmeen, R., Bibi, M., \& Raza, A. (2019). Impact of Organization Politics on Human Resource Management Practices and Employee Performance. SEISENSE Journal of Management, 2(2), 3947. doi: bttps:// doi.org/10.33215/sjom.v2i2.118

Copyright (C) 2019 The Author(s)

\section{(cc) BY}

\author{
College of Physicians and Surgeons Pakistan \\ Bahria University, Karachi \\ Preston University, Karachi
}

\begin{abstract}
Purpose- The purpose of this study was to investigate the impact of nepotism \& favoritism as a form of organization politics on HRM practices and employee performance.

Design/Methodology- Explanatory research design was employed to determine the effect of nepotism \& favoritism on HRM practices and employee performance. Primary data collection method was used among employees working in different public-sector hospitals based on their accessibility. For this study, the sample of 150 employees was used. The adapted questionnaire was used for data collection. Data were analyzed using SPSS.

Findings- The correlation analysis revealed a significant relationship between favoritism, employee performance \& HRM practices whereas nepotism has a significant association with employee performance but the insignificant relationship with HRM practices. The outcomes of the study unveiled a significantly negative effect of nepotism on employee performance \& HRM practices while favoritism has a significantly positive effect on employee performance \& HRM practices.

Practical Implications- The study outcomes might help public sector hospitals HR department to incorporate some changes regarding their policies to prevent the nepotistic \& favoritism practices which can lead to creating a politics in the organization in which everyone works to fulfill his or her selfinterest without focusing towards organizational goals achievement.
\end{abstract}

\footnotetext{
${ }^{1}$ Corresponding author email address: munaza.12star@yahoo.com
} 


\section{Introduction}

Organizational Politics is primarily stated as a certain behavior of a person which includes intentional actions to effect certain decisions to safeguard their personal interest (Ahmed, Baloch, \& Ghani, 2015). Khan and Hussain (2016) asserted that there is a relationship between politics in organization and survival of employee in Pakistan as when employee see others benefiting from organizational politics they are probably to be involved in such behavior. Therefore, nepotism and favoritism phenomena exist in the form of organization politics lead to creating conflicts between employees and employer relationship in all organizations (Firfiray, Cruz, Neacsu, \& Gomez-Mejia, 2018). The primary problem during execution of HRM is the factor of organization politics i.e., favoritism \& nepotism lead to affect the whole process of implementation of HR practices such as recruitment \& promotions as well as employee performance, satisfaction \& commitment in the public sector of Pakistan (Aslam, Arfeen, Mohti, \& Rahman, 2015; Bilal, Rafi, \& Khalid, 2017; Muqadas, Rehman, \& Aslam, 2017).

Karakose (2014) emphasized that unfairness in appointing individuals based on favoritism from the political aspect of the organization ultimately affect the sense of fairness among employees. Favoritism and nepotism lead to creating a political environment within the organization to hold down competition for the higher positions and hinder the career progress of high performers can affect the employee and organizational performance adversely (Safina, 2015). Though the association between organization politics and human resource management appears noticeable, yet there is a lack of empirical studies (Drory \& Vigoda-Gadot, 2010). Nepotism \& favoritism can ensue in utmost all organizations. As (AL-shawawreh, 2016) \& (Ozler \& Buyukarslan, 2011) elucidated that nepotism take place among both countries developed and developing, as well as in both sectors public \& private.

Though limited studies have investigated the nepotism \& favoritism effect on employee performance in the literature. Yet, the review of the extant literature shows that there is no study which investigates the effect of nepotism \& favoritism respectively as a form of organization politics on employee performance and HRM practices. To fill this gap, this paper attempted to determine the effect of nepotism \& favoritism from an organizational politics viewpoint on HRM practices and employee performance in developing country like Pakistan. Therefore, the main objectives of the present study were to investigate the effect of nepotism on employee performance and HRM practices. To examine the effect of favoritism on employee performance and HRM practices.

\section{Review of Literature}

\section{HRM Practices, Employee Performance, and Organization Politics}

Nabi, Syduzzaman, and Munir (2016) stated that human resource practices are comprised of policy \& philosophy to manage a human resource through recruitment, selection, placement, training, compensation, performance assessment and so on. According to Shaukat, Ashraf, and Ghafoor (2015), by executing human resource management, organizations can attract and retain competent individuals that can lead to sustained organizational success. Moreover, fair execution of HR practices such as recruitment, selection \& performance appraisal leads to motivate workers to perform effectually (Choudhury, 2011). In addition, the politics in an organization is linked to the behavior in which members through using power to fulfill their self-interest can influence decisions made regarding employment and promotion (Elbanna, 2010).

Petsri (2014) explains job performance as the behavior of employee associated with their tasks as well as organizational goals. Employee performance of job evaluates whether an individual performs his or her job effectively. In this way, individual performance can be characterized into two i.e., performed a behavior as specified in the description of the job and the second one in response to environment, not directions $(\mathrm{Na}-$ 
Nan, Chaiprasit, \& Pukkeeree, 2018). Besides, Choudhury (2011) stated that employee behavior and performance is influenced by the organizational environment in which they work. In addition, (Li \& Mahadevan, 2017) specified that relationship as one of the dimensions of organization climate affects the performance of employee positively. Organization politics reliant on the environment because it led to developing either political activities such as nepotism or favoritism within the organization (Arasli, Bavik, \& Ekiz, 2006). Sroka and Vveinhardt (2018) explain that when the process of HRM is led by considering nepotism (family relations) or favoritism (condescending workers for friendship rather on the criteria delineating the employee expertise and capabilities can be perceived negatively by employees. In other words, social association whether in the form of nepotism \& favoritism are placed above the organizational interests to safeguard their interest.

Use of power, influence and fulfilment of self-interest among employees and management of organization lead to give birth to the view of organization politics which always have been exist in working environment such as when striving over scarce resources, conflict during important decisions as well as presence of selfinterests among groups or individuals in organization (Butt, Imran, Shah, \& Jabbar, 2013; Schneider, 2016). Therefore, politics is a part of the utmost organizations in some form (Brouer, Harris, \& Kacmar, 2011). Besides, Nunoo (2010) pointed out that the most obvious form of organizational politics is nepotism in both sectors the public and private. Furthermore, Schneider (2016) asserted that when favoritism based personal actions to reward workers for reasons other than prior agreed performance criteria, to specify that politics is more imperative than performance in the organization. Thus, favoritism is considered as a form of organization politics which lead to affect the employee behaviors. On the other hand, favoritism can take place through tendencies of politics \& citizenship to associate with old friends and colleagues in the organization to gain advantages over others (Shabbir, 2017). In this study, nepotism and favoritism were viewed as the forms of organization politics and both were discussed along with their effects on HRM practices and employee performance in the subsequent section.

\section{Nepotism, Employee Performance, and HRM Practices}

Jones and Stout (2015) defined nepotism as actual and perceived predilection given by means of one member of the family to another member. According to Gjinovci (2016), nepotism refers to hiring relations irrespective of their abilities and eventually lead to detrimental consequences for both the organization and the economy. Moreover, when an individual is favored in the organization due to family associations rather than based on his or her capabilities lead to low individual performance and team spirit (Karakose, 2014). In addition, nepotism signifies a threat to the position of the organization due to the nepotistic selection of personnel irrespective of who has been more capable amongst the candidates lead to creating perilous influence on the performance of job (Singh \& Twalo, 2014). On the other hand, Abramo, D'Angelo, and Rosati (2014) pointed out that higher productivity perhaps not only results from higher capacity and commitment but also because of favored treatment in the organization to gain advantages or fulfill their anticipated interests.

Furthermore, working under individual who was appointed based on kinship to higher positions unrelatedly to the skills \& abilities of a person leads to create dissatisfaction, the absence of confidence, decrease in job performance among employees who were not family members (Büte, 2011). Altındağ (2014) elucidates that recruitment through nepotism would not upsurge employee performance. Though there is a condition in which nepotism can increase the performance when the individual recruited is proficient in the related field. Besides, it has been pointed out by Gok and Ekmekci (2015) that nepotism is considered as a negative factor for employee performance. The authors found a significantly negative effect of nepotism on HRM as specified by Arasli et al. (2006) and on employee performance as shown by (Ombanda, 2018). Therefore, for this study the following hypotheses were framed: 
H1: Nepotism has a negative effect on employee performance.

H2: Nepotism has a negative effect on HRM practices.

\section{Favoritism, Employee Performance, and HRM Practices}

Favoritism is demarcated as a biased treatment towards favored individuals who are awarded privileges as compared to those individuals who have not favored ones (Aydogan, 2012). Decisions regarding pay raises \& promotions that are based on favoritism rather on merit as driven by a political culture existence that favors those who are associated with the influential individual of that culture in the organization (Malik, Danish, \& Ghafoor, 2009). Additionally, Favoritism now becomes a common practice in organizations. Due to this reason jobs are not available adequately in both sectors public or private because favorite individuals are indebted during execution of HRM practices particularly during recruitment and promotion hence it leads to low motivation \& performance of employees (Sadozai, Zaman, Marri, \& Ramay, 2012). On the other hand, when employee perceived that the distribution of rewards based on performance rather on favoritism can lead to enhance their employee performance (Ahmad, Danish, Ali, Ali, \& Humayon, 2018).

As Safina (2015) explicates that favoritism is a Latin word derived from favor which means mercy which has the feeling of out of line and biased support of cronies in office to move to higher positions without having capacities nor competence vital for performing such duties. In this manner, favoritism seems like a rule in state and public activity to support the most favorite individual being in the certainty of his boss lead to climbing the profession stepping stool because of a feeling of having been selected. Thus, the subsequent hypotheses were outlined:

H3: Favoritism has a positive effect on employee performance.

H4: Favoritism has a positive effect on HRM practices.

\section{Research Methodology}

In this study, the explanatory research design was employed to determine the effect of nepotism \& favoritism on HRM practices and employee performance. Primary data collection method was used for collection of data among employees working in different public-sector hospitals based on their accessibility. For this study, a total number of 250 questionnaires were distributed only 150 were returned appropriately for further examination. The adapted questionnaire was used for data collection from respondents. In this study, the questionnaire items were employed from different authors (Ahmed., 2018; Büte, 2011; Kazan \& Gumus, 2013). Data were analyzed using statistical tools such as descriptive statistics, reliability, correlation \& regression analysis by utilizing SPSS.

\section{Findings}

\section{Descriptive Analysis}

Table 1 unveiled the descriptive statistics outcomes for employee performance, HRM practices, nepotism, and favoritism. Thus, analysis of descriptive statistics showed that favoritism had a highest mean value $=3.74$ and standard deviation $=1.16$, followed by nepotism mean value $=3.67 \&$ standard deviation $=1.15$ and value of mean for HRM practices $=3.62 \&$ standard deviation $=1.00$. In addition, employee performance had a lowest mean value $=3.55 \&$ Standard deviation $=0.81$. 
Table 1-Descriptive Statistics

\begin{tabular}{lcc}
\hline Variables & Mean & Standard Deviation \\
\hline Nepotism & 3.67 & 1.15 \\
Favoritism & 3.74 & 1.16 \\
Employee Performance & 3.55 & 0.81 \\
HRM Practices & 3.62 & 1.00 \\
\hline
\end{tabular}

\section{Reliability Analysis}

Table 2 disclosed the value of Cronbach alpha of the variables. In this study reliability test was ran to determine the internal consistency of variables respectively. The outcomes of analysis revealed that the value of alpha $=0.842, \mathrm{n}=5$ for nepotism while an alpha value of favoritism $=0.816, \mathrm{~N}=6$. Value of alpha for employee performance $=0.753, \mathrm{~N}=8$. Cronbach alpha value for HRM practices $=0.863, \mathrm{~N}=6$ which was highest amongst all the variables in this study. Thus, all the variables alpha value is within the acceptable range.

\section{Table 2 -Reliability Statistics}

\begin{tabular}{lcc}
\hline Variables & Cronbach Alpha Value & Number of items \\
\hline Nepotism & 0.842 & 5 \\
Favoritism & 0.816 & 6 \\
Employee Performance & 0.753 & 8 \\
HRM Practices & 0.863 & 6 \\
\hline
\end{tabular}

\section{Correlation Analysis}

Table 3 specifies the correlation value among all variables. The outcomes of analysis unveiled that there was a positive correlation between nepotism and employee performance $(\mathrm{r}=0.569, \mathrm{p}<0.05)$. While a weak positive \& insignificant association was detected between nepotism and HRM practices $(\mathrm{r}=0.070, \mathrm{p}>0.05)$. Besides, favoritism displayed a positive $\&$ significant relationship with employee performance $(r=0.667, p<0.05)$ and HRM practices $(\mathrm{r}=0.281, \mathrm{p}<0.05)$.

Table 3-Pearson correlation (Recruitment and Selection, Coaching and Mentoring, Compensation \& Employee Performance)

\begin{tabular}{lcccc} 
Variables $(\mathbf{N}=\mathbf{1 5 0})$ & $\mathbf{( 1 )}$ & $\mathbf{( 2 )}$ & $\mathbf{( 3 )}$ & $\mathbf{( 4 )}$ \\
\hline 1: Nepotism & 1 & & & \\
2: Favoritism & .936 & 1 & & \\
3:Employee Performance & .569 & .667 & 1 & .822 \\
4: HRM Practices & .070 & .281 & .822 & 1 \\
\hline
\end{tabular}

\section{Regression Analysis}

Table 4 shows the multiple regression analysis which discloses that un-standardized beta $(\beta)$ of nepotism and favoritism was $(\beta=-0.241, \mathrm{p}<0.05) ;(\beta=0.756, \mathrm{p}<0.05)$. While value of $\mathrm{R}$ square $=0.470, \mathrm{~F}(2,147)=$ $65.091 \& \mathrm{p}<0.05$. This specifies that nepotism and favoritism elucidate $47 \%$ variation in performance level of employee in public sector hospitals.

Table 4-Regression Analysis to anticipate the employee performance value with respect to Nepotism \& Favoritism

\begin{tabular}{lcccc}
\hline Variables & B & Std. Error & t & Sig. \\
Nepotism & -.241 & .092 & -2.610 & .010 \\
Favoritism & .756 & .119 & 6.365 & .000 \\
& R=0.685 & R2=0.470 & F $(2,147)=65.091$ &
\end{tabular}


Table 5 showed the multiple regression analysis of beta values. The outcomes of study reveal that unstandardized beta $(\beta)$ of nepotism and favoritism was $(\beta=-1.032, \mathrm{p}<0.05) ;(\beta=1.482, \mathrm{p}<0.05)$. On the other hand, $\mathrm{R}$ square exhibit the following values $(\mathrm{R} 2=0.377, \mathrm{~F}(2,147)=44.412, \mathrm{p}<0.05)$. Thus, nepotism and favoritism explain 37\% variation in HRM practices in public sector hospitals.

Table 5-Regression Analysis to foresee the HRM practices value with respect to Nepotism \& Favoritism

\begin{tabular}{lcccc}
\hline Variables & $\mathbf{B}$ & Std. Error & $\mathbf{t}$ & Sig. \\
\hline Nepotism & -1.032 & .123 & -8.380 & .000 \\
Favoritism & 1.482 & .158 & 9.363 & .000 \\
& $\mathrm{R}=0.614$ & $\mathrm{R} 2=0.377$ & $\mathrm{~F}(2,147)=44.412$ & \\
\hline
\end{tabular}

\section{Discussion}

This study primarily engrossed on nepotism \& favoritism as a form of organization politics and its impact on employee performance and HRM practices in public sector hospitals of Pakistan. In this study, the first hypothesis which is nepotism has a significant effect on employee performance is accepted because fallouts are displaying significant but negative effect on employee performance. On the other hand, the second hypothesis i.e., nepotism has a significant effect on HRM practices is accepted as outcomes specify a significantly negative effect on HRM practices. Therefore, the practice of nepotism leads to affect the performance of employee due to the reason that competent employee feels that they are not given the appreciation for the work they do as compared to relatives. The fallouts of study are in accordance with the outcomes of Arasli et al. (2006) \& Ombanda (2018). Third \& fourth hypotheses of this study are also accepted i.e., favoritism has a significant effect on employee performance \& HRM. The consequence of this study is concurrence with the extant literature that favoritism seems, as a rule, to support the most favorite individual regardless of their capacities nor competence vital for performing a job as well as to move to higher positions because of preferential treatment (Safina, 2015).

Hence, this study divulged empirical evidence regarding nepotism \& favoritism as a form of organization politics effect on employee performance \& HRM practices. Thus, for today's organizations, it is a significant aspect to reduce the nepotism \& favoritism practices from top management, middle \& lower level employees \& managers who fulfill their self-interests can create a sense of politics within the organization which subsequently leads to influence the employee performance as well as depict a sense of biased execution of HRM practices among employees. Hence, all hospitals must redefine their policies to prevent this sense of politics within the organization such as nepotism \& favoritism. As the environment is continuously changing now a day, the organization can increase their competitive advantage over others through utilizing the performance of competent \& talented employees (Bibi, 2018). This is possible by employing merit-based practices which lead to enhance the performance of human resource. Therefore, the outcomes of the study reveal that the prevalence of nepotism and favoritism practices in the public-sector hospitals of Pakistan eventually affect employee performance as well as HRM practices positively \& negatively in some way. The current system needs to incorporate some changes regarding their policies to prevent the nepotistic \& favoritism practices which lead to creating a politics within the organization in which everyone works to fulfill his or her self-interest without directed towards organizational goal achievement.

\section{Conclusion}

Public sector hospitals in Pakistan need to focus on the political aspect of the organization in term of nepotism \& favoritism practices as it influences the performance of employees \& HRM practices execution. This study reveals that nepotistic practices affect employee performance and HRM practices negatively. On the other hand, favoritism practices affect employee performance and HRM practices positively. Therefore, 
organizations need to make some effective policies to prevent the political aspect within the organization in the form of nepotism \& favoritism. As this form of politics leads to affect the performance of employees as well as organizational performance. Hence, execution of HRM practices needs to be implemented on merit without being considered the relatives and friends. Future researchers should investigate the effect of nepotism and favoritism as a form of organization politics on HRM practices \& employee performance in other sectors. In addition, the future researcher may also inspect the organization politics in terms of nepotism \& favoritism as mediating variables between HRM practices and employee performance or with some other mediating \& moderating variables. Moreover, studies needed to be examined in the future in which nepotism and favoritism perhaps be inspected with job-related behavior such as absenteeism, work stress, and job satisfaction.

\section{References}

Abramo, G., D’Angelo, C. A., \& Rosati, F. (2014). Relatives in the same university faculty: nepotism or merit? . Scientometrics, 101(1), 737-749.

Ahmad, D. I., Danish, D. R., Ali, S., Ali, H. F., \& Humayon, D. A. (2018). A Comparative Study of Banking Industry Based on Appraisal System, Rewards and Employee Performance. SEISENSE Journal of Management, 2(1), 1-11. doi: 10.33215/sjom.v2i1.64

Ahmed, M., Baloch, A., \& Ghani, H. (2015). The Impact Of Organizational Politics On The Productivity Of Employees: An Empirical Investigation From Pakistan. Gomal University Journal of Research, 31( 2), $122-$ 133.

Ahmed., I. (2018). Organizational Politics and Turnover Intention: A Study From Private Colleges of Pakistan. European Journal of Economic and Business, 3(2), 3-12.

AL-shawawreh, T. B. (2016). Economic Effects of Using Nepotism and Cronyism in the Employment Process in the Public Sector Institutions. Research in Applied Economics, 8(1), 58-67.

Altındağ, E. (2014). Evaluation Of Nepotism As Accelerating Effect On Employee Performance: An Empirical Study In Turkey. European Journal of Business and Social Sciences, 3(7), 97-104.

Arasli, H., Bavik, A., \& Ekiz, E. H. (2006). The effects of nepotism on human resource management: The case of three, four and five star hotels in Northern Cyprus. International Journal of Sociology and Social Policy, 26(7/8), 295-308.

Aslam, U., Arfeen, M., Mohti, W., \& Rahman, U. (2015). Organizational cynicism and its impact on privatization (evidence from federal government agency of Pakistan. Transforming Government: People, Process and Policy, 9(4), 401-425.

Aydogan, I. (2012). The existence of favoritism in organizations. African Journal of Business Management, 6(12), 4577-4586.

Bibi, M. (2018). Impact of Talent Management Practices on Employee Performance. SEISENSE Journal of Management, 2(1), 22-32. doi: 10.33215/sjom.v2i1.83 
Bilal, A. R., Rafi, N., \& Khalid, S. (2017). Detrimental Causes And Consequences Of Organizational Injustice In The Workplace: Evidence From Public Sector Organizations. Pakistan Business Review, 19(1), 114137.

Brouer, R. L., Harris, K. J., \& Kacmar, K. M. (2011). The moderating effects of political skill on the perceived politics-outcome relationships. Journal of Organizational Behavior, 32(6), 869-885.

Büte, M. (2011). The Effects of Nepotism and Favoritism on Employee Behaviors and Human Resources Practices: A Research on Turkish Public Banks. TODAĐE's Review of Public Administration, 5(1), 185208.

Butt, M. R., Imran, A., Shah, F. T., \& Jabbar, A. (2013). Perception of Organizational Politics and Job Outcomes in a Public Sector Organization: The Moderating Role of Teamwork. Middle-East Journal of Scientific Research, 18(9), 1268-1276.

Choudhury, M. G. (2011). The Dynamics of Organizational Climate : An Exploration. Varanasi In Research Scholar, Faculty of Management Studies, Banaras Hindu University

Drory, A., \& Vigoda-Gadot, E. (2010). Organizational politics and human resource management: A typology and the Israeli experience. Human Resource Management Review, 20(3), 194-202.

Elbanna, S. M. (2010). Making Strategic Decisions: A State of the Art Review and Empirical Evidence from a Cultural Perspective: Lambert Academic Publishing.

Firfiray, S., Cruz, C., Neacsu, I., \& Gomez-Mejia, L. R. (2018). Is nepotism so bad for family firms? A socioemotional wealth approach. Human Resource Management Review, 28(1), 83-97.

Ginovci, A. (2016). The impact of nepotism and corruption on the economy and HR. Economic and Environmental Studies, 16 (3), 421-434.

Gok, M. S., \& Ekmekci, M. (2015). Effects of Reengineering, Nepotism and Mobbing on the Employee Performance. Review of Public Administration and Management, 3(1), 3-6.

Jones, R. G., \& Stout, T. (2015). Policing Nepotism and Cronyism Without Losing the Value of Social Connection. Industrial and Organizational Psychology, 8(01), 2-12.

Karakose, T. (2014). The Effects of Nepotism, Cronyism and Political Favoritism on the Doctors Working in Public Hospitals. Studies on Ethno-Medicine, 8(3), 245-250.

Kazan, H., \& Gumus, S., 2. (2013). Measurement of Employees' Performance: A State Bank Application. International Review of Management and Business Research, 2(2), 429-441.

Khan, M. A., \& Hussain, N. (2016). The Analysis Of The Perception Of Organizational Politics Among University Faculty. Pakistan Business Review, 18(2), 451-456.

Li, Y. P., \& Mahadevan, A. (2017). A Study On The Impact Of Organisational Climate On Employee Performance In A Malaysian Consultancy. International Journal of Accounting \& Business Management,, 5(1), 1-13. 
Malik, M. E., Danish, R., \& Ghafoor, M. (2009). Relationship between Age, Perceptions of Organizational Politics and Job Satisfaction. Journal of Behavioural Sciences, 19(1-2), 1.

Muqadas, F., Rehman, C. A., \& Aslam, U. (2017). Organizational Justice And Employee's Job Dissatisfaction: A Moderating Role Of Psychological Empowerment. Pakistan Business Review, 18(4), 848-864.

Na-Nan, K., Chaiprasit, K., \& Pukkeeree, P. (2018). Factor analysis-validated comprehensive employee job performance scale. International Journal of Quality \& Reliability Management, 35(10), 2436-2449.

Nabi, M. N., Syduzzaman, M., \& Munir, M. S. (2016). The Impact of Human Resource Management Practices on Job Performances: A Case Study of Dhaka Bank Pvt. Ltd., Bangladesh. Human Resource Management Research, 6(2), 45-54.

Nunoo, A. (2010). Organisational Politics - A Human Resource Management Focus. Pentvars Business Journal, $4(2), 77-89$.

Ombanda, P. O. (2018). Nepotism and Job Performance in the Private and Public Organizations in Kenya. International Journal of Scientific and Research Publications, 8(5), 474-494.

Ozler, E. D., \& Buyukarslan, A. B. (2011). The Overall Outlook Of Favoritism In Organizations: A Literature Review. International Journal Of Business And Management Studies, 3(1), 275-284.

Petsri, C. (2014). The follower characteristics and organizational climate influencing operational efficiency of employees: a case study of the information and communications technology business group. Suthiparitha, 28(85), 145-160.

Sadozai, A., Zaman, H. M., Marri, M. Y., \& Ramay, D. M. (2012). Impact Of Favoritism, Nepotism And Cronyism On Job Satisfaction A Study From Public Sector Of Pakistan. Interdisciplinary Journal Of Contemporary Research In Business, 4(6), 760-771.

Safina, D. (2015). Favoritism and Nepotism in an Organization: Causes and Effects. Procedia Economics and Finance, 23, 630-634.

Schneider, R. C. (2016). Understanding and Managing Organizational Politics. Paper presented at the In Sixth AsiaPacific Conference on Global Business, Economics, Finance and Social Sciences, Bangkok-Thailand.

Shabbir, B. (2017). Impact of Nepotism, Cronyism, and Favoritism on Organizational Performance with a Strong Moderator of Religiosity. International Journal of Scientific \& Engineering Research, 8(4), 11.

Shaukat, H., Ashraf, N., \& Ghafoor, S. (2015). Impact of Human Resource Management Practices on Employees Performance. Middle-East Journal of Scientific Research, 23(2), 329-338.

Singh, P., \& Twalo, T. (2014). Impact Of Human Factors On The Labour Process: A Case Study. International Business \& Economics Research Journal, 13(2), 305-318.

Sroka, W., \& Vveinhardt, J. (2018). Nepotism and favoritism in the steel industry: a case study analysis. Forum Scientiae Oeconomia, 6(1), 31-46. 